\title{
Maintaining Public Order in \\ France: Myths and Realities
}

\author{
Alain Bauer \\ Professor of Criminology at the Conservatoire National des Arts et Métiers \\ New York and Shanghai
}

$$
\text { ABSTRACT }
$$

The maintenance of law and order in France, which was long an object of pride and a French export, has considerably evolved over time. Faced with more mobile and sometimes more violent populations, and without any means of internal control, the police have to adapt and rethink their ideology.

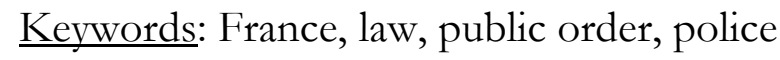

Whether it involves the insurrectional demonstrations of 1934 or the cobblestones thrown at police during the May 1968 events, a confused amnesia governs politicians about the very nature of maintaining public order in France.

It took a very long time for the management of demonstrations to be demilitarized and for rioting crowds to no longer be shot at (1921 and 1945, respectively). This slow de-escalation went hand in hand with the very gradual creation of specialized units that would become the Gendarmerie mobile and the CRS. Regional Compagnies d'intervention (public order forces) were also introduced, in particular in Paris. Management of the MO (Maintenance of Order) was not completely handled by experts in the field.

The principles of maintaining public order therefore adapted according to events. It reached its height in 1979 with the demonstration by steelworkers in Paris. As so often occurs, and in line with the customs of the period, this led to a duel, or a tournament, between security personnel of the CGT and the forces of law and order on a commonly defined terrain and shared timetable. This was followed by a confrontation with the rioters (known as "autonomes" or "totos" by those close to them). 
1986 saw a mobilization of the student movement, and especially of highschool students, who discovered a new way of demonstrating. At the head of the procession of marchers, and in front of the security forces, a young demonstrators"nebula" stood between the CRS and the trade union security team in order to challenge them. In the years that followed, this very militant young crowd changed tactics, and took to moving along the demonstration to pillage shops or even steal from other demonstrators in the procession itself. Each tense episode (1994 (CIP), 1995 (Juppé Pensions), 2003 (Fillon Pensions), 2006 (CPE), 2016 (El Khomri), etc.) led to a modification of procedure and to variations: these became tougher and more organized for anti-globalization gatherings and more spontaneous during the 2003 riots following the deaths of two children in an electrical substation.

On each occasion, after first being dumbfounded and then adjusting to the new situation, the forces of law and order adapted, regaining the upper hand, and a political solution took shape (usually by withdrawal of the offending provision). But, alas, there is a great ability to forget where policing is concerned-a domain that is very rarely run by the police themselves and much more often by experts in public order.

2018 was not 1934. The fascist leagues did not run the movement, but they took advantage of the opportunity. Neither was it 1968, when a process began in a high school and spread through a crisis of abundance and liberalization in a conservative society trapped in a black and white vision of the world (contrary to what is said, it led to at least three deaths). Neither was it 1986 (which had a symbolic victim). And we should not forget Vital Michalon, who died at Creys Malville in 1977, or Remi Fraisse who died at Sivens in 1994.

2018 brought together multiple grievances for the first time, yet without managing to combine disparate and often contradictory battles.

The maintenance of law and order has therefore been confronted with a crisis that is unprecedented in nature, although far from surprising for the state.

Indeed, in 1987, the Prefect Massoni organized a very rare and very discreet feedback session on the events of the previous year. In addition to General Inspector Berlioz, who was at the forefront of the exercise, other experts participated in a major reorganization of the system for maintaining law and order. 
The Pelotons Voltigeurs Motorisés [Motorized Squads] were abolished—this had been a temporary unit set up around sports coaches and motorcyclists from the Prefecture of Police, who operated in pairs on their vehicles, chasing and striking supposedly violent demonstrators with their "bidules" (long wooden truncheons). They were directly condemned for the death of Malik Oussekine. But, more than this, crowd management needed to be reinvented for the modern era.

The method conceived of at the time aimed to prevent Agincourt (as if it had happened a fortnight before, in Paris), Maginot (as if it were last week) and especially Waterloo (which never took place). This revolution in policing operations included mobile units used in a mobile manner, mixed units (uniformed and civilian), functioning in a legal capacity, with a process determined in agreement with the Public Prosecutor's office and under the control of district attorneys. It was designed to be preventative by anticipating places of departure, routes taken, or arrival points of participants deemed to be dangerous.

The idea of armored vehicles was quickly abandoned, because these vehicles (including those used by the gendarmerie on December 8th) are very difficult to control in towns or outside of an OPEX (exterior operations) conflict.

Although the question of cellphones and the increased mobility of crowds were envisaged, nobody foresaw the effects of social networks-evidence enough that it will be necessary to do more than simply adapt the principles for maintaining law and order. A total and rapid rethink is what will be needed —in order to guarantee the freedom to demonstrate and the right to protest; to ensure that whatever power is in place responds to the people it governs; because the security response is only ever a stopgap enabling uprisings to be contained, to reopen dialogue, and to establish consultation. But this has never prevented a Revolution. 